\title{
THE UNITED NATIONS SECURITY COUNCIL AND THE INTERNATIONAL COURT OF JUSTICE: CO-OPERATION, CO-EXISTENCE, AND CO-INVOLVEMENT
}

\author{
Jaemin Lee*
}

\begin{abstract}
The Security Council is more than a political power tool. It is an organ with important responsibilities derived from the Charter. The authority of the Council will not be diminished, but enhanced, if it accepts that its decisions are not above the law. There is no contradiction between the rule of law and international peace and security. ${ }^{1}$
\end{abstract}

\section{INTRODUCTION}

Through diplomatic fluctuations, expansion of the United Nations Security Council ("Security Council") is finally being discussed at the various entities of the United Nations as a part of the general effort to reform the world body. ${ }^{2}$ In this process, the issue which attracts the keen attention from member states, as is well known, concerns whether to expand the number of permanent members from the current 15 to 24 , and, if so, whom to include. ${ }^{3}$ It appears that Japan, Germany, India, and Brazil are the most likely candidates for the new Security Council. It is regrettable, however, that this important effort fails to reform the United Nations in general; the Security Council in particular fails to focus on a more fundamental issue that would significantly affect the future of the United Nations and the Security Council: how to create a mechanism to apply international law to the actions of the Security Council in order

\footnotetext{
"Associate Professor of Law, Hanyang University, Seoul, Korea. LL.B, LL.M., Ph.D from Seoul National University, Seoul, Korea; Juris Doctor from Boston College Law School, Newton, Massachusetts, USA; LL.M. in International Legal Studies from Georgetown University Law Center, Washington, DC., USA.

This paper shared the Sata Prize with that of Naazima Kamardeen, which appears in this volume. 1 Martenczuk, Bernd, "The Security Council, the International Court and judicial review: what lessons from Lockerbie?", 10 EJIL (1999), at 547.

2 BBC, "Annan urges sweeping U.N. reforms", BBC News World Edition (21 March 2005).

${ }^{3}$ Chambers, Madeline, "Talks on U.N. Security Council expansion to continue", Reuters (25 July 2005).
}

Asian Yearbook of International Law, Volume 12 (B.S. Chimni et al., eds.)

(C) 2007 Koninklijke Brill NV. Printed in The Netherlands, pp. 57-81. 
to enhance "rule of law" within the operation of the Security Council. This crucial issue seems to be missing in the current debates at the United Nations

As the role of the Security Council has dramatically expanded after the demise of the Cold War confrontations, ${ }^{4}$ so has international concern for and criticism of the role of the Security Council. Many countries, especially those in the Third World, view the Security Council as an apparatus that implements the strategies and plans of a few permanent member countries in order to uphold their national interests, especially in the case of the United States, rather than to maintain international peace and security. The criticism of the Security Council basically boils down to the claim that the most important entity of the United Nations fails to pay adequate attention to the basic norms of international law; it attempts to address international issues only from the political perspective. The proposition that the United Nations and the Security Council are subject to the norms of international law as provided in the Charter of the United Nations ("Charter") is not refuted. What is not clear, however, concerns who or which agency has the authority to check and determine whether a particular action of the Security Council is consistent with international law. This "uncertainty" has caused a great deal of confusion and controversy whenever there is a legally dubious action adopted by the Security Council. This paper attempts to address this issue.

This paper concludes that all duly-constituted international courts preserve the inherent authority judicially to review the consistency of an action of the Security Council with the applicable norm of international law. Needless to say, the most important and influential judicial body among various international courts is the International Court of Justice ("ICJ"). Henceforth, judicial review of Security Council actions by the ICJ is the most important topic in addressing this particular issue; the current paper focuses mainly on the judicial review authority of the ICJ. Although various domestic courts of member states may judicially review relevant actions of

4 Watson, Geoffrey R., "Constitutionalism, judicial review, and the World Court", 34 Harv. Int'l L. J. (1993), at 1; Most of the sanctions by the Security Council based on its enforcement action under Chapter VII of the U.N. Charter have taken place since the 1990s, since the Security Council was revitalized by the demise of the Cold War. The first state against which the Security Council applied sanctions was Rhodesia in 1965; the next was South Africa in 1977, and all others (including Iraq, Yugoslavia, Somalia, and Libya) were sanctioned in the 1990s after the Cold War. See Kirgis, Frederic L., International Organizations in Their Legal Setting, (St. Paul, Minn., West Publishing Co., 1993), at 620. One commentator described the advent of the newly charged Security Council in 1990s as follows. "With a metaphor that, like most metaphors, is not altogether accurate, the UN Security Council could be described as a whale which, for reasons known and unknown, lay quietly somewhere on the high seas for most of its life. Some ten years ago, the whale awoke and turned over once or twice, sending waves to distant shores which, in turn, set in motion the ships and boats and canoes of legal science. They are still nervously cruising while the whale, as it turned out, did not really leave its place.” Fassbender, Bardo, "Quis judicabit?: The Security Council, its powers and its legal control”, 11 EJIL (2000), retrieved from the EJIL website at http://www.ejil.org/ journal/vol11/no1/br1.html, at 1 . 
the Security Council in accordance with domestic statutes or constitutions - some of such reviews may constitute violations of international law if such review is not consistent with the member states' obligation under relevant international treaties including the Charter - the focus here is only on the issue of judicial review by the ICJ of the actions of the Security Council. Similarly, other international tribunals may also exercise judicial review in the course of their evaluation of a particular case. Yet again, however, this is not the focus of the discussion of this paper.

This paper first discusses the fundamental limitations on the Security Council operation as imposed by the Charter. The paper then enquires into relevant ICJ precedents and Charter provisions to analyze the relationship between the Security Council and the ICJ, and to confirm that the ICJ is indeed allowed judicially to review an action (most notably, the binding resolutions and decisions) of the Security Council. This paper also notes the unique characteristics of the function carried out by the Security Council, and fundamental differences between the municipal judicial system and international judicial system. As such, this paper concludes that a judicial review by the ICJ should be a harmonious, indirect one, which duly takes into account these unique aspects of a judicial review mechanism under the current structure of the United Nations. It then suggests a framework to assist the ICJ in carrying out its judicial review of the Security Council actions in more effective and reasonable manner.

\section{THE SECURITY COUNCIL IS NOT ABOVE INTERNATIONAL LAW: LIMIT OF THE SECUERITY COUNCIL'S ACTIONS}

Is the Security Council is immune from basic norms of international law? Should the Security Council be free from the restriction of international law because the Council carries out such an important function under the Charter? The answer to these two questions is simple and clear: No. The following discussion proves this.

\subsection{The Ultra vires doctrine}

Under international law, every international organization, unlike a state, has a limited international personality with an inherent restriction attached. ${ }^{5}$ In other words, international organizations are authorized to operate only to the extent stipulated by a constitutional instrument explicitly, which is a distinctive trait of international organizations as contrasted with those of states. If an organization attempts to carry out an act beyond the authorized boundary in the constitutional document, then it

\footnotetext{
5 See Malanczuk, Peter, Akehurst's Modern Introduction to International Law, $7^{\text {th }}$ Revised edn. (London: Routledge, 1997), at 93.
} 
would constitute an ultra vires activity, which is null and void $a b$ initio. ${ }^{6}$ As a matter of fact, this is an inevitable, logical conclusion because the power of an international organization comes only from the mandates from each member state participating in the international organization; thus, as a corollary, an organization cannot exercise an authority that has not been delegated in the first place. Meanwhile, no state may delegate power that the state does not possess originally. In other words, only the power that lies within the proper boundary of each state can be reassigned to an international organization, and the organization constituted as such, in turn, has international personality only within the delegated boundary. An international organization is created by the "collective accumulation" of individual authorities of individual members; therefore, the power or authority of an international organization could on occasion be greater than that of a member state. Nonetheless, the fundamental principle still remains the same: the organization does not in the first place possess the authority which each member does not possess, because it cannot and has not been delegated.

The United Nations is an international organization established by a treaty: the Charter. Its power as an organization thus stems only from the Charter precisely as delegated by each member state. As regards the Security Council, however important a role it may play, it remains simply a sub-organization of the United Nations and, as a sub-organization, its authority cannot exceed that of the umbrella authority. Therefore, the Security Council is also subject to the same limitations applicable to the United Nations. The Security Council is also bound by the Charter. ${ }^{7}$ Thus, it is logically self-evident that there is from the outset a limitation upon the actions of the Security Council. ${ }^{8}$

As such, there is no logical reason not to apply the theory of ultra vires in the context of the Security Council operation. It should therefore be remembered, as a principle from which to start, that whenever the Security Council exercises its power, this is valid only when performed within the boundaries of the Charter provisions. Similarly, another inevitable result is that the Security Council does not possess the power which individual states do not originally own. In other words, unlike tempting arguments to the contrary, there is indeed a limitation on the actions of the Security Council under the Charter; consequently, any resolution adopted in violation of the Charter should be considered null and void as an ultra vires action, at least theoretically speaking.

It is true, as opponents of this theory strenuously argue, that even if such an adoption be null and void, there is no entity in the current international society that

${ }^{6}$ See Certain Expenses of the United Nations, ICJ Rep.1962, at 167-68 ("Neither purposes nor powers conferred on the U.N. to effectuate the purposes are unlimited." The Ultra vires doctrine could apply "when the organization takes action which does not warrant the assertion that it was appropriate for the fulfillment of one of the purposes.").

7 Martenczuk, loc. cit., note 1, at 534.

${ }^{8}$ David, Marcella, "Passport to justice: Internationalizing the political question doctrine for application in the World Court", 40 Harv. Int'l L. J. (1999) at 81, 113; see Sabahi, Babback, loc. cit., n. 57 , at 12 . 
can officially pronounce such nullification of the actions of the Security Council or sanction the Security Council for that matter. ${ }^{9}$ However, when a social norm is deemed a law, the lack (or weakness) of an enforcement mechanism or of declaratory entities does not necessarily stimulate a conclusion that the norm is not law at all. Its coercive nature is indeed an important factor of law, yet is not always dispositive. As such, the fact that no entity in the international community can issue an enforceable judgment vis-à-vis the Security Council does not lead to the conclusion that the body is immune from the international law in general and the ultra vires doctrine in particular.

\subsection{Charter provisions}

This principle of "limited authority" is also contained in the Charter provisions. According to the Charter, one of the purposes and principles of the United Nations is to settle international disputes, and to maintain international peace and security "in accordance with international law" (emphasis added). ${ }^{10}$ Articles 1 and 2 of the Charter also make it clear that all actions of the United Nations must be in conformity with various international law principles. Therefore, actions of a United Nations body - including the Security Council - must be in conformity with international law. Actions of the United Nations bodies violating international legal norms thus automatically constitute ultra vires activities, as far as the United Nations as an international organization is concerned, as well as constituting a violation of applicable substantive international law. Again, theoretically speaking, such international law-violating ultra vires activities of the United Nations bodies, including the Security Council, are to be viewed as null and void $a b$ initio, as explained above. $^{11}$

Despite this obvious fact, there are commentators who believe that the Security Council is authorized to carry out its duty without constraint from other international law principles, mainly based on Article 103 of the Charter, which provides that "the obligation under the Charter overrides other obligations from other agreements." 12

\footnotetext{
9 Judge Schwebel mentioned in his dissenting opinion that "the Court is particularly without power to overrule or undercut decisions of the Security Council determining whether there is a threat to the peace and what measures shall be taken to deal with the threat." See Judge Schwebel's Dissenting Opinion in the Judgment on Preliminary Objections in the Questions of Interpretation and Application of the 1971 Montreal Convention arising from the Aerial Incident at Lockerbie (Libyan Arab Jamahiriya v. United Kingdom, Libyan Arab Jamahiriya v. United States of America, 27 February 1998) (hereinafter, the Pan Am 103 case), found at www.icj.org.

${ }_{10}$ See Article 1 of the Charter.

${ }^{11}$ Fassbender, loc. cit., n. 4, at 4 ("The decisions of the Security Council are presumed to be legal. If this presumption is rebutted, an illegal decision is void," citing Michael Fraas' statement.).

12 See Judge Schwebel's dissenting opinion in the Judgment on Preliminary Objections, loc. cit., n. 9. ("Security Council resolutions supervene any rights of Libya under the Montreal Convention, and thus render reliance upon it without object and moot.").
} 
They then attempt to combine Article 103 with Article 25 which, in turn, provides the Security Council with the power to issue a "binding" decision. The outcome of this combination makes every Security Council resolution superior to obligations arising from any other treaty or agreement, they argue. ${ }^{13}$ Stated differently, the Security Council is entitled to issue a resolution that is in conflict with an existing international treaty, and that resolution 'trumps' the contradictory treaty. A simple reading of Articles 103 and 25 does seem to lead to such a conclusion.

The more proper analysis, however, requires a more in-depth examination of the issue as opposed merely to a technical reading of these provisions in the Charter. Even if Article 103 of the Charter recognizes the superiority of the Charter obligation over other "treaty" obligations, that provision, just as any other provision in the Charter, should always be interpreted in harmony with the basic purposes and principles of the Charter as defined in Articles 1 and 2. The spirit of Article 103 certainly is not that "the Security Council can carry out its action even through violation of international law" thus invalidating the basic principles of the Charter as provided in Articles 1 and 2.

More significantly than any other factor, the initial hurdle to be cleared in recognizing the superiority of a Security Council action in the context of a combination scheme of Articles 25-103 is that the action at issue (the resolution) must be a valid one under the Charter, both procedurally and substantively. In other words, barring any procedural defect, ${ }^{14}$ only the actions of the Security Council that have been performed in conformity with the basic principles of international law (i.e., in accordance with international law, to borrow the wording from the Charter) are given binding authority under Article 25, and only then are such resolutions eligible for the superiority consideration under Article 103.

In this regard, there is an important issue to note. Given the fact that Article 103 is introduced to "override" other treaties that impose contradictory obligations on member states, the term "international law" should be interpreted to mean the set of international law except the treaty to be superseded by a particular Security Council action (a resolution). If the term "international law" also includes the international law as created by the contradictory treaty, the Security Council would never issue a resolution that contravenes any other international treaty. Certainly, that is not the purpose of the Charter, either. The Security Council's resolution should be in conformity with the various principles of international law, except with those specific provisions of a treaty to be overridden by the resolution.

Thus, a proper way of interpreting those provisions would be that Article 103 is operable as a rule of hierarchy only when there is a conflict between a "valid" treaty, on the one hand, and a "valid" Security Council resolution, on the other. It is simply untenable to interpret Article 103 in a way that gives the Security Council the virtually limitless authority to ignore a valid existing treaty even if such an action undermines the basic principles of the Charter. The ordinary meaning of Articles

\footnotetext{
13 See ibid.

14 For example, resolutions which have been adopted without concurrent affirmative votes from the five Permanent Members would fall into this category. See Article 27 of the Charter.
} 
25 and 103 may, technically, lead to such a conclusion, yet when ordinary meaning clearly goes against the fundamental principles and underlying purposes of the Charter, it simply cannot stand.

Article 103 does not mean that the Security Council may execute whatever it wants regardless of international treaties and agreements $;{ }^{15}$ it was not designed to provide the Security Council with a royal immunity. Rather, it should be read to mean that only those Security Council actions that have been adopted through valid procedures in furtherance of the Charter objectives may be given such status. Article 103 should not be invoked as a ground to nullify valid existing international treaties simply because this would hinder the achievement of a particular goal of the Security Council.

Other aspects of Article 103 further support this conclusion. The obligation under Article 103 is described as the obligation of "states," not as the obligation of any United Nations organ. It could therefore be argued that United Nations bodies such as the Security Council are not necessarily bound by the Article $;{ }^{16}$ this in turn means that, unlike the case with member states, the Article does not require the Security Council and other United Nations bodies to afford the superior status of the Charter over a treaty. This would support the proposition that the Security Council cannot hide behind Article 103 in justifying its violation of existing international law.

At the same time, Article 103 mentions only "treaty." Thus, it could be argued that it does not grant superiority over customary international law. When the Charter mentions international law in Article 1, it does not expressly or implicitly set aside a customary portion (or any other portion, for that matter) of it. ${ }^{17}$ Therefore, all branches of international law are applicable to the member states and to United Nations organs. Accordingly, states and the United Nations as an international organization are still bound by customary law (that is, important principles of international law, such as the equality of sovereign rights) if there exists one applicable to the specific situation posed, irrespective of Article $103 .{ }^{18}$ All of these points

\footnotetext{
15 See Judge Schwebel's dissenting opinion in the Judgment on Preliminary Objections, n. 9. ("The terms and drafting history of the Charter demonstrate that the Security Council is subject to the rule of law, and at the same time is empowered to derogate from international law if the maintenance of international peace requires.").

${ }^{16}$ Gardam, Judith G., "Legal restraints on Security Council military action", 17 Mich. J. Int'l L. (1996), at 285, 304.

${ }^{17}$ For example, the Articles of Agreement of the World Bank have implicitly made clear that some provisions are applicable despite existing contradictory customary international law. For example, the World Bank can order a variety of measures that may interfere with the national sovereignty of a recipient state as a quid pro quo of a loan.

${ }_{18}$ Professor Franck says that if Libya had accepted a compulsory jurisdiction under Article 36 (2) of the Charter, and had brought a claim against Great Britain which accepted the compulsory jurisdiction, unlike the United States, then it could have resorted to general principles of international law, such as customary law, to demonstrate the violation of its sovereign rights, without having to limit its claim to the interpretation of the Montreal Convention. If that were the case, he signals, Libya would have stronger case here. Franck, Thomas, "The "Powers of Appreciation": Who is the ultimate guardian of U.N. legality?", 86 AJIL (1992), at 519, 522.
} 
collectively stand for the proposition that Articles 103 and 25 combined do not provide the Security Council with the full immunity to violate international law.

\subsection{Positions of the ICJ}

Actual practice of the ICJ will shed more light on this issue. The ICJ has indeed since 1945 exercised judicial review over the actions of the United Nations bodies. As these were done in an indirect, roundabout manner, it may be called a de facto judicial review.

The first example came in the Conditions of Admission case in 1948 when the General Assembly requested an advisory opinion regarding the validity of imposing additional admission conditions not stipulated in Article 4 of the Charter. ${ }^{19}$ Rejecting the consideration of other elements than those provided in Article 4, the ICJ has recognized that there are legal limits to the powers of the respective United Nations organs. ${ }^{20}$ The ICJ reasoned that "the political character of an organ cannot release it from the observance of the treaty provisions established by the Charter when they constitute limitations on its powers or criteria for its judgment. ${ }^{21}$ To ascertain whether an organ has the freedom of choice over its decisions, reference must be made to the terms of its constitution."22 This broad language applies not only to the United Nations admission issue, but also to virtually any other act by a political organ that arguably runs counter to express conditions imposed by relevant constituent instruments. Viewed from that perspective, the Security Council, although a highly political organ, is still subject to the provisions of the Charter, and its actions are valid only when they are done pursuant to the Charter. ${ }^{23}$

In 1962, the ICJ issued another advisory opinion pursuant to the General Assembly's request concerning the burden sharing of the peace-keeping operations in the Congo and Middle East. ${ }^{24}$ The question was whether those peace-keeping-related expenses were the "expenses of the Organizations" as provided in Article 17 (2) of the Charter. ${ }^{25}$ In ruling that the expenses are indeed covered by Article 17 (2), the ICJ provided a meaningful indication recognizing the judicial review authority of the ICJ. ${ }^{26}$ Ignoring the General Assembly's blatant attempt to avoid the ICJ's review

\footnotetext{
19 See Conditions of Admission of a State to Membership in the United Nations, Advisory Opinion (1948) ICJ Rep. 1948, at 57.

20 See ibid.

21 Ibid.

22 Ibid

23 Ibid.

24 Certain Expenses of the United Nations, Advisory Opinion (1962), ICJ Rep. 1962, at 151.

25 See ibid.

26 Ibid.
} 
in its request for advisory opinion, ${ }^{27}$ the ICJ held that "it must have full liberty to consider all relevant data available to it in forming an opinion on a question posed to it for an advisory opinion," despite the fact that the General Assembly's intention was clearly otherwise. ${ }^{28}$ In addition, the ICJ further reasoned that "when the Organization takes action which warrants the assertion that it was appropriate for the fulfilment of one of the stated purposes of the United Nations, the presumption is that such action is not ultra vires. ${ }^{, 29}$ In other words, such a non-ultra vires presumption may be overcome when a disputed action is not "appropriate for the fulfilment of one of the stated purposes of the United Nations," ultimately making the action ultra vires. One of the stated purposes of the United Nations is to preserve and enhance international law. If a Security Council action undermines relevant international law, such an action is not to preserve and enhance international law, hence is not appropriate to the fulfilment of one of the stated purposes of the United Nations. The Security Council action would therefore be an ultra vires activity, and the ICJ would refuse to accord it legal validity, according to the rationale in the Certain Expenses case.

This position was also maintained in the Namibia case in $1971 .^{30}$ South Africa had been governing southwest Africa (now known as Namibia) under the trusteeship authorization since the era of the League of Nations. South Africa had applied its infamous apartheid policy in that region despite international criticism, which prompted the General Assembly and the Security Council to adopt respective resolutions to terminate the trusteeship. ${ }^{31}$ South Africa then challenged the resolutions as ultra vires action, and the Security Council referred the matter to the ICJ for an advisory opinion. In that case, the ICJ did review the validity of the resolutions and concluded that they were constituted within the boundary of the Charter provisions. ${ }^{32}$

Since it was the Security Council itself that asked for advisory opinions in these cases, one may well argue that the Security Council, not the ICJ, has an inherent right to engage in a so-called "practical" judicial review of its own actions, using the ICJ as a judicial advisor. To some extent, such an argument may sound plausible, but it fails to provide an accurate characterization of the situations involved. This is because the Security Council has here merely the power to request the ICJ to provide an opinion: not to make a decision itself. The review is done by the ICJ,

\footnotetext{
27 France proposed to formulate the request for an advisory opinion in a more direct way, which was rejected by the General Assembly. That is, the rejected French amendment asked for a two-step decision whether the General Assembly and the Council had acted ultra vires in authorizing the expenditure, and then asked for an opinion whether such expenditure lay within the "expenses of the Organization."

28 See the Certain Expenses case, n. 24, at 167-68.

29 See ibid.

30 Legal Consequences for States of the Continued Presence of South Africa in Namibia notwithstanding Security Council Resolution 276, Advisory Opinion (1971), ICJ Rep. 1971, at 16.

31 See Gross, L., "The South West Africa case: What happened ?", 45 Foreign Affairs (1966), at 36, reprinted in Kirgis, op. cit., n. 4, at 485-89; See also U.N.GAOR, U.N.Doc. GA/ RES/ 2145 (27 October 1966) and U.N. SCOR, U.N. Doc. SC/RES/ 276 (30 January 1970).

32 See the Namibia case, n. 30, at 16.
} 
and it is the ICJ's judicial review as such. If there exists a fundamental reason prohibiting the Security Council from judicially reviewing a Security Council action, a request from the Security Council should not and could not cure the defect: the ICJ is performing a step it should not take. On the contrary: the fact that the Charter explicitly allows the ICJ to provide advisory opinions at the request of the Security Council indicates that at least the Charter does not impose a fundamental hindrance to the ICJ's judicial review. Furthermore, this decision also indicates that as long as a case is legitimately brought before the ICJ, the United Nations judicial organ can legitimately review an action by the Security Council which is implicated in the case. In this instance, the case was appropriately brought before the ICJ through the request for an advisory opinion by the Security Council.

In furtherance of that logic, the ICJ made another significant stride in the Pan Am 103 case. There, the ICJ hinted that, if necessary, it could judicially review a Security Council resolution which violates the Charter or treaty obligations. ${ }^{33}$ This is the first contentious case in which the ICJ signalled that it has the power judicially to review a Security Council action. Given the importance of the case, a brief explanation of the background to the case seems helpful.

Pan Am flight 103 flying from Frankfurt to New York via London was blown out of the sky over Lockerbie in Scotland on 21 December 1998, killing all 216 people on board, most of them American soldiers returning home for Christmas, and eleven on the ground. ${ }^{34}$ Thanks to a three-year-long investigation by American and British terrorist specialists, sufficient evidence was collected to show that the Libyan Intelligence Service was apparently behind the explosion. ${ }^{35}$ Consequently, the United States and the United Kingdom demanded the extradition of the two Libyan agents involved for trial in the US or the UK. ${ }^{36}$ The request was, however, denied by the Libyan government on the grounds that the request violated relevant international law. ${ }^{37}$ The two countries then turned to the Security Council, of which both are permanent members, asking for its action since the dispute constituted a threat to international peace and security. ${ }^{38}$

The Security Council then, under its Chapter VII authority, adopted a series of resolutions: Resolutions 731 (21 January 1992), ${ }^{39} 748$ (31 March 1992), ${ }^{40}$ and 883 (11 November 1993), ${ }^{41}$ ordering Libya to turn over the requested agents to the US or the UK governments, and imposing severe economic sanctions when Tripoli refused

33 See the Judgment on Preliminary Objection of the Pan Am 103 case, n. 9.

34 See generally, Martenczuk, loc.cit., n. 1, at 520-22.

35 See ibid.

36 Ibid.

37 Ibid.

38 Ibid.

39 U.N. SCOR, 3033d mtg., U.N. Doc. S/RES/731 (1992).

40 U.N. SCOR, 3036d mtg., U.N. Doc. S/RES/748 (1992).

41 U.N. SCOR, 3312 ${ }^{\text {th }}$ mtg., U.N. Doc. S/RES/883 (1993). 
to obey. ${ }^{42}$ In the meantime, the Libyan government resorted to the ICJ for the settlement of the case, ${ }^{43}$ citing the jurisdictional provision of the 1971 Montreal Convention for the Suppression of Unlawful Acts against the Safety of Civil Aviation ("Montreal Convention") that arguably confers jurisdiction of the dispute on the ICJ. ${ }^{44}$ The Convention clearly provides that terrorist attacks against a civilian aircraft, such as the Lockerbie incident, fall under the jurisdiction of the ICJ ${ }^{45}$ and all three countries were indeed parties to the Convention. ${ }^{46}$ In addition, there were other provisions that arguably support the position held by Libya ${ }^{47}$ The gist of Libya's claim was to enjoin the US and the UK from pressing their claims for the extradition of two Libyan nationals through the enforcement of the Security Council action, arguing that it has the legal right not to extradite them under the Montreal Convention $^{48}$ and as well under customary law. ${ }^{49}$

42 The extradition demand is extraordinary in and of itself because under customary international law, a state has no obligation to extradite its own nationals in the absence of treaty obligations to that effect. Here, the only treaty obligation for these three states concerned is the Montreal Convention for the Suppression of Unlawful Acts against the Safety of Civil Aviation (23 September 1971) (hereinafter the "Montreal Convention") which aims at punishing acts of terrorism against a civilian aircraft. See Articles 1, 7, 8 of the Montreal Convention.

${ }^{43}$ Libya filed two separate, but virtually identical, applications against the United States and the United Kingdom respectively on 3 March 1992. See n. 9; see also History of the Proceeding contained in Press Communique 2000/27 (13 September 2000), retrieved from the ICJ website at www.icj.org.

${ }^{44}$ Article 14 (1) of the Montreal Convention provides that "[a]ny dispute between two or more Contracting States concerning the interpretation or application of this Convention which cannot be settled through negotiation, shall, at the request of one of them, be submitted to arbitration. If within six months from the date of request for arbitration, any one of those Parties are unable to agree on the organization of the arbitration, any one of those Parties may refer the dispute to the International Court of Justice by request in conformity with the Statute of the Court."

${ }^{45}$ See Articles 1 and 14 (1) of the Montreal Convention.

46 The United States and the United Kingdom also acknowledge that Libya has the right and can claim it under the Montreal Convention. However, they argue that the right is superseded by the Security Council resolutions. See the Judgment on Preliminary Objections of the Pan Am 103 case, n. 9 , at paras. 37-38.

47 The provisions invoked by Libya in its applications are Articles 1, 5 (2), 5 (3), 7, 8 (2), 11 (1), and 14 (1) of the Montreal Convention.

${ }^{48}$ Libya's argument runs that: Article 7 of the Convention declares the principle of "aut dedere aut judicare," which gives the custodial state of terrorist suspects the choice between extradition to other requesting states with jurisdiction, or indicting them itself. Furthermore, even if an extradition obligation arises (say, by not prosecuting the criminals), Libya's obligation under the Convention is subject to its domestic law under Article 8 (2) of the Convention that provides "Extradition is made subject to the laws of the State from which extradition is requested." Libyan law, furthermore, as do those of many other states, proscribes the extradition of its own nationals. Accordingly, Libya arrested the two named suspects and asked, in preparation for the prosecution of the crime, the American and British authorities to turn over to them the relevant information, as is provided in the Montreal Convention. 
On the other hand, based upon the vast evidence accumulated by the joint American-British investigation team linking the bombing to the Libyan Intelligence Service, ${ }^{50}$ the US and the UK concluded that the bombing was perpetrated by two agents of the Libyan Intelligence Service in retaliation for the 1986 US air raid over Tripoli and Benghazi. ${ }^{51}$ Despite such cold facts, it is also true that Libya has accumulated significant support in the international community and among international scholars for its assertion that the Security Council's backing of the American and British demands is inconsistent with applicable international law and therefore infringes on its sovereign rights. ${ }^{52}$ To outsiders, there was obviously an unambiguous appearance of a biased decision by the Security Council. ${ }^{53}$

The principal argument of the US and the UK is that even if Libya has the proper right to refuse the extradition of its nationals under the Montreal Convention, the treaty-based right has been negated by the Security Council resolutions under Article 103 of the Charter. ${ }^{54}$ They further argue that Article 25 requires Libya as a member state of the United Nations to "accept and carry out the decisions of the Security Council in accordance with the present Charter,"

Libya first asked for provisional measures, mentioning irreparable harm imminent from the pending Security Council resolutions; these were rejected by the ICJ. ${ }^{55}$ In the merit phase, however, while rejecting the long, persistent argument of the

49 Even if there is a sign of a changing trend, traditionally, civil law states do not usually extradite their own nationals. This principle is usually included in their national law and extradition treaties. Gilbert, Geoff, Aspects of Extradition Law (Dordrecht/Boston/London, Martinus Nijhoff Publishers, 1991), at 95-100.

${ }^{50}$ There was irrefutably concrete evidence to ascertain Libya's involvement in the bombing. For example, the bomb's Toshiba timing device was one of twenty delivered to a Libyan official. Zubel, Eric, "The Lockerbie controversy: Tension between the International Court of Justice and the Security Council”, 5 Ann. Surv. Int'l \& Comp. L. (1999) at 261.

${ }^{51}$ See "France-United Kingdom-United States: Statements calling on Libya to cooperate in investigations of aerial incidents at Lockerbie and Niger, Announcement by the Lord Advocate of Scotland on November 14, 1991", 31 ILM (1992) at 718.

${ }^{52}$ See e.g., David, loc. cit., n. 8, at 88; Franck, loc. cit. n. 18, at 520; Teson, Ferrando, "Collective Humanitarian Intervention", 17 Mich. J. Int'l L. (1996), at 323; Gowlland-Debbas, Vera, "The Relationship between the International Court of Justice and the Security Council in light of the Lockerbie Case", 88 AJIL (1994), at 643.

${ }^{53}$ This case shows the arguably strong appearance of the impartiality of Security Council's resolutions: two permanent members are parties to the dispute and one (France) has a strong interest in the outcome. David, ibid., at 117-18. France has a strong interest in the outcome of the case, because the French government also indicted six Libyan Intelligence Agents in its domestic courts in absentia for the bombing of UTA flight 772 over Niger that killed 171 people.

${ }^{54}$ See the remarks of David Andrews (representing the US) at the Oral Hearing held on 14October 1997 at the Peace Palace, The Hague, Verbatim Record of the Hearing, para. 1.22; John Crook's argument for more details contained in the same document, both retrieved from the ICJ website retrieved at www.icj.org.

${ }_{55}$ Order Denying Provisional Measures, Questions of Interpretation and Application of the 1971 Montreal Convention Arising from the Aerial Incident at Lockerbie (Libyan Arab Jamahiriya v. United States), ICJ Rep. 1992, at 114. 
Washington and London governments that the ICJ had no jurisdiction over a matter in which the Security Council was exercising its power under the Charter, ${ }^{56}$ the ICJ decided in favour of Libya in 1998 by recognizing its jurisdiction over the case. ${ }^{57}$

Although the ICJ managed to find technical loopholes allowing it to avoid a headon collision with the Security Council ${ }^{58}$ and the case was subsequently settled among the three states in 2003 as a result of the diplomatic negotiations and ensuing thaw among the parties, the Pan Am 103 case presented a striking institutional challenge to the current United Nations constitutional system. ${ }^{59}$ Despite heated controversy, ${ }^{60}$ this case offered clear indication that the ICJ does possess the authority to review judicially a particular action of the Security Council and in the future the ICJ may exercise its judicial power over the same issue as that being addressed by the Security Council.

In the Israeli Wall Case in 2004, the ICJ provided the same logic in its discussion of the jurisdiction of the ICJ and the political nature of the Security Council. In the case, the ICJ held that it could not accept the view that it had no jurisdiction over the Israeli-Palestinian dispute over Israel's construction of a separation wall because

${ }^{56}$ Some have argued that the ICJ's failure to avoid a direct conflict with the Security Council is reckless and misguided, as it might seriously prejudice the effectiveness of the Council which will, in turn, lead to the eventual disintegration of the UN. See David, loc. cit., n 8, at 91.

57 This is the Judgment on the Preliminary Objections filed by the US and UK, loc. cit., note 9. For a brief history of the case: after its application for provisional measures was rejected, Libya filed Memorials on 19 June 1992; the US/UK filed Counter-Memorials on 31 March 1999; Libya filed its Replies on 29 June 2000, and Rejoinders from the US/UK were due on 3 August 2001. The case then remained as pending for about three years until it was finally dismissed, as the three parties settled it through diplomatic negotiations in 2003. See History of the Proceedings, loc. cit., n. 43, at 2; see also the Case Concerning Questions of Interpretation and Application of the 1971 Montreal Convention Arising from the Aerial Incident at Lockerbie (Libya v. U.K.), ICJ Rep. 2003, ordering the case to be removed from the docket of the Court. One commentator opined that this withdrawal forced the Court "to lose the opportunity to hear the merits of and pronounce itself upon one of the most controversial issues that it had encountered since its inception." Sabahi, Babback, "The ICJ's authority to invalidate the Security Council's decisions under Chapter VII: Legal romanticism or the Rule of Law", 17 N.Y. Int'l L. Rev. (Summer 2004), at 1.

58 The ICJ tactfully avoided the question of the validity of the Security Council's resolution by simply noting that Libya's application to the ICJ pre-dated the adoption of the Council resolution. See the Judgment on Preliminary Objections, loc. cit., n. 9, at para. 38. However, Judge Sir Robert Jennings in his dissenting opinion wondered whether the ICJ had sufficiently weighed the gravity of dealings with a question involving binding and peace-keeping decisions of the Security Council in so technical, not to say legalistic, a fashion. See his dissenting opinion in the Judgment on Preliminary Objections. One commentator also characterized the Preliminary Objection ruling of the ICJ as "extremely cautious." See Martenczuk, loc. cit., n. 1, at 525.

${ }^{59}$ David, loc. cit., n. 8, at 82; Andrews, loc. cit., n. 54, at para.1.3; Franck, loc. cit., n. 18, at 520 ("The similarities of the Libyan case to Marbury extend beyond judicial tactics. Both raise the specter of political actors exercising powers mala fide and ultra vires and what courts are to do about them.").

${ }^{60}$ The Lockerbie cases have produced a lively debate on the limits of the Security Council powers, and on the question of how these limits could be enforced. Martenczuk, loc. cit., n. 1, at 518. 
of the "political" character of the questions posed. ${ }^{61}$ The ICJ also reasoned that the fact that "a legal question also has a political aspect does not suffice to deprive it of its character as a legal question and to deprive the Court of a competence expressly conferred on it by its Statute. ${ }^{\circ 2}$ In short, the ICJ indicated that as long as jurisdictional basis is appropriately ascertained, it should and will exercise its jurisdiction over a highly political question, including over the actions of the Security Council.

These ICJ precedents collectively support the conclusion that even under the current Charter scheme the ICJ is empowered to review an action of the Security Council. As long as requirements for the ICJ's intervention are met, such as a request by an eligible United Nations body for an advisory opinion, ${ }^{63}$ or the existence of jurisdiction in a contentious case, then the current Charter does not comprise an obstacle to the ICJ's judicial review.

\section{MORE IN-DEPTH EXAMINATION OF THE CHARTER PROVISIONS: THE ICJ'S AUTHORITY FOR A JUDICIAL REVIEW AS A “PRINCIPAL AND PRINCIPLED JUDICIAL ORGAN"}

Despite the lack of explicit wording, there are many relevant provisions scattered throughout the Charter which, when combined, unambiguously support the judicial review authority of the ICJ. First of all, it should be noted that the United Nations system itself does not attempt to give the Security Council an "exclusive" power even in matters of maintaining international peace and security. Under the United Nations scheme, the Security Council has only the "primary" responsibility, not the "exclusive" responsibility, for the maintenance of international peace and security. ${ }^{64}$ In other words, the Charter does not preclude other principal organs of the United Nations from deliberating issues of international peace and security: the other bodies also possess their own respective, even though secondary, responsibilities in maintaining international peace and security.

A good example in this regard appears to be the "Uniting for Peace" Resolution in $1950 .^{65}$ When it was proved that the Security Council was sometimes unable to fulfil its duty under the Charter, as was obviously shown in its dealing with the Korean War in June 1950, the General Assembly passed a resolution in which the General Assembly was authorized to take necessary actions in the Security Council's

${ }^{61}$ See Summary of the Advisory Opinion in Legal Consequences of the Construction of a Wall in the Occupied Palestine Territory (9 July 2004) ("Israeli Wall Case"), retrieved from the ICJ website at www.icj.org, at 4.

${ }^{62}$ Ibid.

63 A request for an advisory opinion should also be made by an eligible United Nations organ for an issue falling under the jurisdiction of the body. Otherwise, it would be subject to an ultra vires challenge by other states and bodies. See Summary of the Advisory Opinion in Israeli Wall Case, loc. cit., n. 61, at 2 .

${ }^{64}$ See Article 24 of the Charter.

${ }^{65}$ U.N. GAOR, U.N. Doc. GA/Res/ 377 (V), (3 Nov. 1950). 
stead to maintain international peace and security. ${ }^{66}$ When its legality was later challenged in the Certain Expenses case, the ICJ ruled that the General Assembly's exercise of de facto enforcement action did not violate the Charter; this was achieved through holding that the Security Council's responsibility is only a primary, not and exclusive, one; the peace-keeping operation performed under this resolution was found a valid exercise of the General Assembly's authority under the Charter. ${ }^{67}$ In other words, even if the issue was unambiguously about maintaining international peace and security, the General Assembly could nonetheless deal with the issue if such an exercise falls within the boundaries of the General Assembly's independent authority. Viewed from this standpoint, an argument that all issues having an impact on international peace and security are exclusively reserved for the Security Council's deliberation has no logical ground in the Charter.

Secondly, it follows as a corollary that, as the principal (and principled) judicial organ of the United Nations, ${ }^{68}$ the ICJ should have a legitimate power, by necessary implication, to review "any" legal issues arising from the actions of the United Nations bodies, ${ }^{69}$ even if that review inevitably touches upon issues of international peace and security. ${ }^{70}$ In the world of globalization in the twenty-first century, it is hard to imagine a topic totally detached from the issue of international peace and security, since all aspects interwoven with all others in one way or another. Moreover, there is no specific substantive restriction on the issues to be dealt with by the ICJ. ${ }^{71}$ On the contrary: Article 96 provides that "the Security Council may request the ICJ to give an advisory opinion on any legal question"72 (emphasis added).

Also, Article 12 appears to provide another strong support for the notion that there is no restriction on the substantive issues dealt with by the ICJ. Article 12 offers the clear intent of those who framed the Charter that the General Assembly should refrain from discussing an issue when the same topic is being discussed by the

\footnotetext{
66 See ibid.

67 Ibid. This position was also confirmed by the ICJ in the Preliminary Objection phase of Military and Paramilitary Activities In and Around Nicaragua ("Nicaragua Case"), ICJ Rep. 1984, at paras. 91-98.

68 See Article 92 of the Charter.

${ }^{69}$ In fact, there are no matters that are, by nature, excluded from judicial review a priori. Fassbender, loc.cit., n. 4 , at 4 .

70 Under international law, the Organization must be deemed to have those powers which, though not expressly provided in the Charter, are conferred upon it by necessary implication as being essential to the performance of its duties. See Reparation for Injuries Suffered in the Services of the United Nations. Advisory Opinion (1949), ICJ Rep. 1949, at 174.

71 Neither the UN Charter nor the ICJ Statute provides for any restrictions on the freedom of the ICJ to act. Simma, Bruno (ed.), The Charter of the United Nations: A Commentary (New York, Oxford University Press, 1994), at 403.

72 See Article 96 of the Charter. In the Nicaragua Case, the ICJ reasoned that the status as principal judicial organ allows it to deal with "any legal questions." It thus stated: "It is for the Court, the principal judicial organ of the U.N., to resolve any legal questions that may be in issue between parties to the dispute." See the Nicaragua Case, ICJ Rep. 1984, at paras. 433-34. The merit of the case was determined in 1986.
} 
Security Council. If the framers wanted the same result with respect to the ICJ, they could easily have included the same or similar language in Chapter XIV of the Charter because they obviously knew how to deal with such an overlapping jurisdiction situation. An "inference" to apply Article 12 to the ICJ is not appropriate, either, because a sound argument could be made that there is a clear distinction between the General Assembly and the ICJ: the former is a political organ, which basically shares the same character with the Security Council, whereas the latter is a judicial organ, completely different in nature and applying different standards in resolving a dispute. A functional division of power between two political organizations, which is common, cannot be presented, as the only ground on which to curtail the function of a judicial organ.

Thirdly, the functions of the Security Council and the ICJ concerning the settlement of disputes are exercised independently of one another. ${ }^{73}$ They apply different standards: the ICJ has to decide exclusively on the basis of international law under Article 38 of the ICJ Statute, ${ }^{74}$ whereas the Security Council has to decide primarily according to political criteria. ${ }^{75}$ Treating them as performing fundamentally the same function would make of the term "principal judicial organ" merely empty words. There is no point in having a "principal judicial organ" if that organ is deprived of the power to exercise its judicial power (at least to provide its judicial opinion) over one branch of the organization, the function of which is the key element of the organization's success. ${ }^{76}$ Furthermore, if the ICJ were compelled to give legal effect to ultra vires actions of the Security Council, it would lead to paradoxical results, given the other provisions of the Charter.

Lastly, there are many other less visible yet relevant Articles scattered within the Charter that provide helpful guidance. Article 36 (3) provides that in making recommendations, the Security Council "should also take into consideration that legal disputes should as a general matter be referred by the parties to the International Court of Justice." 77 Article 92 says that the ICJ Statute "forms an integral part of the present Charter", and Article 93 further mentions that all members of the United Nations become ipso facto parties to the Statute. ${ }^{78}$ The judges of the ICJ are elected by joint votes in the General Assembly and the Security Council, ${ }^{79}$ and the expenses

73 Simma, op. cit., n. 71, at 990.

74 See Article 38 of the ICJ Statute.

75 Simma, op. cit., n. 71, at 403.

${ }^{76}$ Judge Weeramantry pointed out in his dissenting opinion in the ICJ's decision to reject Libya's application for provisional measures: "[T] $]$ he Court must recognize its role as the principal judicial organ of the United Nations charged with the task, inter alia, of deciding in accordance with international law such disputes as are submitted to it. The Court acts as a guardian of the Charter and of international law in international arena, and there is no higher body charged with judicial functions and with the determination of questions of interpretation and application of international law."

77 See Article 36 (3) of the Charter.

78 See Articles 92 and 93 of the Charter.

79 See Article 4 of the ICJ Statute. 
of the ICJ are borne by the UN. ${ }^{80}$ In addition, the Security Council should endeavour to ensure that states have recourse to the ICJ to settle their legal disputes. ${ }^{81}$ Article 94 further expects the Security Council to assist the prevailing party in seeking its relief as granted by the ICJ when the losing party fails to comply with the judgment of the ICJ. ${ }^{82}$ In a nutshell, these Articles all support the argument that the ICJ was envisioned as having and is entitled to have at least some sort of judicial review power over the acts of the other political bodies of the United Nations.

In any event, if the framers did want the ICJ to be powerless for the judicial review purpose despite these provisions, they could probably have inserted unambiguous language to that effect in the Charter. When ambiguous, as here, the question should be resolved by finding "necessary implication" from construing all of the relevant provisions with the purposes and principles of the organization in mind.

As has been clearly indicated by many examples in both domestic and international governmental structures, there is no inherent obstacle to the exercising by a political organ and a judicial organ of dual jurisdictions over the same issue as long as one organ does not undermine the integrity of the other. In other words, the question should be where the line should be drawn between the authorities of the two organs such that the balance of power between them is maintained. The exact location of the line may differ from organization to organization depending upon the nature of the organization involved, but there must be a line if the organization were to claim its existence as being based on both the law and on legal principles.

Such being the case, when a case is legitimately brought before the ICJ - that is, when a proper jurisdiction of the ICJ as provided in the Charter and the Statute is ascertained - it is the duty of the ICJ to review and settle legal issues when there is no other ground on which to decline to exercise the jurisdiction. For example, in a contentious case, there should be mutual consent to the ICJ's jurisdiction among the parties; ${ }^{83}$ for an advisory opinion, the request from the General Assembly or the Security Council to that effect should first be obtained. ${ }^{84}$ When that condition is fulfilled, there is no explicit prohibition in the Charter that bars the ICJ from reviewing the Security Council's resolution in the course of exercising its jurisdiction in that particular case.

On the other hand, the lack of coercive power on the part of the ICJ to force the Security Council to follow the ICJ's decision does not necessarily support the conclusion that the Charter framers failed to consider a scheme of judicial review. Even if an advisory opinion were not binding, and a decision in a contentious case is binding only upon the parties in that particular case,${ }^{85}$ it can nonetheless serve as guidance in the future action of the United Nations organs, including those of the

\footnotetext{
80 See Article 33 of the ICJ Statute.

81 See Article 36 (3) of the Charter.

82 See Article 94 of the Charter.

83 See Article 36 of the ICJ Statute.

84 See Article 65 of the ICJ Statute.

85 See Article 59 of the ICJ Statute.
} 
Security Council and member states. The mere implication of illegality or abnormality would have as strong an impact as explicit judgment in nullifying the action at issue. ${ }^{86}$ Given that which has been experienced and witnessed over the decades since the creation of the United Nations, such non-binding opinions of the ICJ have produced almost the same impact on the behaviours of the United Nations and its members. This has been made possible through the so-called "mobilization of shame" effect ${ }^{87}$ or by establishing new customary law. Needless to say, having a coercive power is an essential element in the administration of law, be it municipal or international; it is, however, not an indispensable element in recognizing and developing law, especially in the international law system where, unfortunately, no central enforcement agency exists as of now. ${ }^{88}$

\section{A HARMONIOUS JUDICIAL REVIEW: A JUDICIAL REVIEW WITHOUT DIRECT COLLISION}

When it comes to the judicial review of a Security Council action by the ICJ, many observers would be concerned about the possible judicial supremacy of the ICJ, where the judges' opinion overthrows a Security Council resolution, as has been seen in municipal settings. The judicial review, however, does not necessarily have to be limited to the case of the "judicial supremacy" version, in which the ICJ can vitiate a Security Council action after a direct petition for review by an individual state: this was illustrated by Judge Schwebel's argument in the Pan Am 103 case.

${ }^{86}$ Louis Henkin's eloquent explanation is helpful in this context. He wrote: "It is probably the case that almost all nations observe almost all principles of international law and almost all of their obligations almost all of the time. Every day nations respect the borders of other nations, treat foreign diplomats and citizens and property as required by law, observe thousands of treaties with more than a hundred countries." How Nations Behave - Law and Foreign Policy, 2nd edn. (New York, Columbia University Press, 1979), at47. This is also confirmed by the compliance record of ICJ decisions. One commentator reviewed the compliance record of the ICJ decisions since 1987 to fathom how the state parties respond as a result of the ICJ decisions. The record shows a solid, although not perfect, compliance by states which have been parties to the respective ICJ procedures. See generally Paulson, Colter, "Compliance with final judgments of the International Court of Justice since 1987", 98 AJIL (2004), at 434; see also Ren, Kathleen and Cronin-Furman, "The International Court of Justice and the United Nations Security Council: Rethinking a complicated relationship", 106 Colum L. Rev. (2006), at 447.

87 See ILO Conventions regarding the functions and authority of the Committee of Experts.

${ }^{88}$ Roger Fisher pointed out that an organized force is not essential to the compliance of the law. He said: "When, in the Youngstown case, the Supreme Court ordered the Secretary of Commerce to return the steel mills which the President had ordered him to seize, the Court had no regiment at its command. But despite the fact that the Supreme Court sitting in Washington had no greater force at its command vis-à-vis the Government than does the International Court of Justice sitting at The Hague, the steel mills were returned. The more closely one examines law within this country and within others, the less significant the element of force." Fisher, Roger, "Bringing law to bear on governments", 74 Harv. L. Rev. (1961), at1132. 
This mode of "direct" judicial review will bind all United Nations organs in all future cases as in the judicial review by domestic supreme courts of many countries.

It is doubtful, however, whether such system will prove feasible or helpful in the current decentralized international order composed of independent sovereign actors. It would indeed be problematic to apply such a "direct" judicial review formula to the international setting where central legislative, judicial or enforcement mechanism is still lacking. It is not practical for the 15 -member ICJ to operate as the highest entity in the United Nations and the ultimate decision maker for the international community. Unfortunately, the member states are not ready to accept an international society in which a judicial organ has the final say in the operation of the United Nations, nor does the current Charter envision such a judicial supremacy system. ${ }^{89}$ That will become possible only when a much higher degree of homogeneity and organization is attained in the future. Unless and until such a point is reached, the ICJ may consider a variety of "indirect" judicial review whenever it is called upon to examine or give effect to a Security Council resolution, both in the advisory opinion situation and the contentious case context.

Even a cautious, indirect approach will still be meaningful as an effective alternative to "direct" judicial review. Mere warnings of illegality or suggestions of alternative options from the ICJ may well serve as a check on the ultra vires or unlawful activity of the United Nations bodies, including of the Security Council. The ICJ cannot force the Security Council to take a particular measure in a particular case; however, the next time the Security Council faces a similar issue, it will be more likely that the Security Council will pay attention to the Charter principles and procedures as interpreted by the ICJ. The Pan Am 103 case itself is a good example of this analogy: although the ICJ decided its merits as based only upon an issue of technicality, namely, the filing date of the Libyan government, there was a clear indication that the resolution adopted under the auspices of the US and the UK may have experienced some legal problems. These two countries and other countries in similar situations would probably pay closer attention to such issues in any future case. In that respect, any judicial evaluation by the ICJ of a Security Council action, equipped with legal terms and standards, will have its own raison d'être. ${ }^{90}$

\footnotetext{
89 Apparently, the framers, too, did not want to have this supremacy model of judicial review when they incorporated Article 59 of the ICJ Statute, which provides that the decision of the ICJ has no binding force except between the parties and in respect of that particular case. Even the supporters of the judicial review by the ICJ also recognize that, even if there is a review, the issue of whether the ICJ can strike down or invalidate the Security Council's measures still remains unresolved. See Sabahi, loc. cit., n. 57, at 4.

${ }_{90}$ Advisory opinions, even non-binding, have far-reaching effect. Simma, op. cit., n. 71, at 979.
} 


\section{HOW TO AVOID IRRESPONSIBLE JUDICIAL ACTIVISM: SUGGESTION FOR A TWO-STEP ANALYSIS}

Any judicial review by the ICJ, whether "direct" or "indirect," should not turn into irresponsible judicial activism. Given the harsh reality of international society as a highly volatile, decentralized entity, coupled with the urgent need quickly to tackle vital issues, time is of the essence when the Security Council is faced with various kinds of international emergencies. ${ }^{91}$ The judicial review by the ICJ must not, therefore, hamper the otherwise legitimate implementation of duties by the Security Council. To filter unbridled judicial activism by the ICJ, a two-step analysis may be helpful.

The first step is a procedural issue. This concerns whether a particular case has been brought legitimately before the ICJ. If the answer is in the affirmative, there should be a presumption that the ICJ's handling of the case is, including all relevant actions by the Security Council, reasonable and legitimate, hence not a case of inappropriate judicial activism. To the extent the ICJ exercises its judicial review function strictly as based upon the Charter provisions by following the jurisdictional requirements for, respectively, advisory opinions and contentious cases, such exercise alone, without more, should not be construed as irresponsible judicial activism by the ICJ. Stated differently, once the ICJ has legitimate jurisdictional basis for a particular case and the case involves a legal analysis of the Security Council action, the ICJ's review of the action itself should not constitute inappropriate judicial activism on the part of the ICJ. A party participating in the case may challenge the ICJ's decision by arguing that the case has not properly been brought before the ICJ; an ultimate decision on that issue will, however, probably be reserved to the ICJ because it is a "jurisdictional" issue where a court has the final say.

The second step in evaluating the ICJ's judicial review of the Security Council action to determine whether it is the ICJ's proper implementation of its duty or its attempt at improper judicial activism involves substantive issues. In other words, the ICJ should exercise its prudential judgment in reviewing an action of the Security Council lest its judicial intervention undermine the integrity of the function of the Security Council. As such, even if a jurisdictional ground is ascertained, its "justiciability" needs carefully to be examined in each case in order to ensure that the ICJ does not exceed its authority. This is especially important where, as here, the danger of disrupting an international decision-making process through multifarious voices is much more obvious and the resulting diplomatic impact is farther-reaching and more expansive.

Despite apparent differences in scope and elements, domestic jurisprudence dealing with this type of issue will probably offer guidance in this issue. Setting aside

${ }^{91}$ In Rwanda, the delay to the Security Council action caused the deaths of 800,000 people in less than 100 days. See the PBS documentary film on the Rwanda genocide and the failure of the UN mechanism, broadcast in 1999. 
the traditional paradigm of a dichotomy between international law and municipal law, it is the time for scholars of international law to offer a creative idea. ${ }^{92}$

There may be instances where judicial involvement is totally undesirable, and where judicial process is simply being abused as an excuse to delay a prompt action of the Security Council..$^{93}$ At the other end of the spectrum, there may be instances where the Security Council is simply pushing forward with its decision of which the illegality, either substantively or procedurally, is manifest on the surface. ${ }^{94}$ Most of the cases before the ICJ would lie between these two extremes within the spectrum. In each instance, therefore, the ICJ will have to locate cases scattered along the spectrum while keeping in mind that a wider scope of judicial review will probably distort the Security Council's enforcement action under Chapter VII, while a narrower scope of judicial review will make of the ICJ a paper tiger rendered harmless by the powerful Security Council. A guideline to help the ICJ to navigate through this labyrinth is thus in order.

If the question of this nature is raised in a US court, the political question doctrine will firstly come into play in most instances. Although other countries also have a similar jurisprudence of judicial restraint, the American one seems to have provided the most organized rationale in this regard. Similar jurisprudence from other countries will, however, be equally applicable to this analysis. As one American commentator mentioned, "the political question doctrine is a useful tool for demarcating the responsibility to interpret the Constitution that is shared by the courts and the political branches." 95 To the extent that it is believed that the political question doctrine has successfully assisted the American courts in filtering non-justiciable cases, this doctrine may be a good candidate for transplant, mutatis mutandis, to the ICJ in this

\footnotetext{
92 Gardam, loc. cit., n. 16, at 285.

93 Judge Schwebel provides us with a good example: a country having committed an aggression against its neighbour applies to the Court when targeted by the Council for an enforcement action under Chapter VII for the purpose of delaying such action. See the Judgment on Preliminary Objections, loc. cit., n. 9, at 627; Andrews, loc. cit., n. 54, at para. 1.3 ("Libya's claims are nothing more than a collateral attack on the decisions taken by the Security Council in its efforts to maintain international peace and security.").

94 For example, it is possible that a Security Council decision in fact adjudicates a legal dispute between the two states. The Security Council therefore operates as a de facto judicial entity in a particular situation. In this case, it is axiomatic that the ICJ can review and decide on the legality of such a Security Council decision when the matter duly comes before the ICJ.

95 Mulhern, J. Peter, "In defense of the political question doctrine", 137 U. Pa. L. Rev. (1988), at 97. The usefulness of the political question doctrine, as developed in the US jurisprudence, in addressing these issues is further evidenced by the fact that in the course of the ICJ procedures the United States has made efforts in addressing the admissibility issue involving highly political disputes, and that many other states also tend to refer to US arguments on admissibility in one way or another in subsequent ICJ procedures. See Gray, Christine, "The use and abuse of the International Court of Justice: Cases concerning the use of force after Nicaragua”, 14 EJIL (2003), at 869-81.
} 
process. ${ }^{96}$ As one commentator suggested, the internationalization of the political question doctrine may provide the best vehicle for the ICJ to identify those legal claims with the potential to undermine the integrity of the Security Council. ${ }^{97}$ Indeed, the Security Council's function mainly includes political, diplomatic, and military components quite similar to those of the executive branch under the American Constitution, ${ }^{98}$ and political question jurisprudence is frequently raised in these areas. It goes without saying that disputes involving questions concerning the legality of the actions of the Security Council pursuant to Chapter VII tend to be of a highly political nature. ${ }^{99}$ In addition, unlike the U.S. Constitution, where an explicit textual basis for political question doctrine is absent, there is a textual ground for the ICJ to refuse to give any legal opinion even if it has an arguable jurisdiction to do so. Article 65 of the ICJ Statute provides that "The Court may give an advisory opinion", that is, it has no obligation to comply with the request for an advisory opinion. The framers might have thought that the ICJ would have to maintain a way to get around an inappropriate case for a judicial organ.

At any rate, the US court's approach to political question is well explained by Justice Brennan of the US Supreme Court in Baker v. Carr, 369 US 186 (1962). The elements to be considered by the US Supreme Court in declining to exercise its otherwise valid jurisdiction are: (i) a textually demonstrable constitutional commitment of the issue to a coordinate political department; (ii) a lack of judicially discoverable and manageable standard for resolving the issue; (iii) the impossibility of deciding the issue without an initial policy determination of any kind clearly for non-judicial discretion; (iv) the impossibility of a court's undertaking an independent resolution without expressing a lack of the respect due coordinate branches of government; (v) an unusual need for unquestioning adherence to a political decision already made, and (vi) the potential for embarrassment from multifarious pronouncements by various departments on one question. ${ }^{100}$

${ }^{96}$ As a matter of fact, Judge Sir Robert Jennings also raised this point in his dissenting opinion in the Judgment on Preliminary Objections. ("The Court should have found that it did not have jurisdiction in the case; and even if it had jurisdiction, that the Libyan case should have been dismissed as inadmissible."); American representative also mentioned the same possibility in the oral argument. See Andrews, loc. cit., n. 54, at para. 1.3.

${ }^{97}$ See David, loc. cit., n. 8, at 82.

98 It may seem appropriate to compare the distribution of the functions of the UN Organizations among the principal organs with the constitutional separation of powers of the supreme organs of national governments. Simma, op. cit., n. 71, at 978 ; The multilateral treaty popularly called "the UN Charter" in important ways resembles the Constitution of the United States, insofar as it establishes a system for the exercise of designated powers by the two political organs of the United Nations: the General Assembly and the Security Council. Franck, loc. cit., n. 18, at 520.

${ }_{99}$ Martenczuk, loc. cit., n. 1, at 528.

100 Justice Powell of the United States Supreme Court once explained in Goldwater v. Carter, 444 U.S. 996 (1979), that the issue is fundamentally reduced to the following three questions: (i) Does the issue involve the resolution of questions committed by the text of the Constitution to a coordinate branch of Government?; (ii) Would resolution of the question demand that a court move beyond 
This list does furnish a good starting point for the ICJ's judicial review analysis. The Pan Am 103 case may be evaluated by this standard: (i) first of all, a legal issue is reserved for the ICJ by a "textually demonstrable constitutional commitment," namely the Charter; (ii) there is a judicially discoverable and manageable standard to resolve the dispute, namely, the interpretation of the Montreal Convention, and the customary international law concerning the non-extradition of nationals; (iii) the core issue in this case is the extradition of the alleged terrorists for a trial, which is not a policy decision at first glance, but rather a legal one; (vi) pronouncing a legal opinion on the surrendering of two suspects does not give rise to the level of lack of respect due the Security Council, ${ }^{101}$ as an objective evaluation of the dispute would only enhance the respect for the Security Council; (v) there is no unusual need of questioning a political decision already made in this case, since, unlike an impending war, there is no exigency in obtaining custody of the suspects with sufficient evidence already accumulated, and (vi) as many nations were already doubting the legality of the Security Council's demand for extradition, a legal decision had to be made to clarify the uncertainty, rather than to compound a confusion triggered by multifarious voices.

All in all, in applying the political question doctrine as outlined above, if the case had proceeded with more meaningful substantive analyses in Pan Am 103, the ICJ could have refused to apply the political question doctrine and reached an ultimate decision in that case. If the ICJ adopts the political question doctrine in a particular case, this means it dismisses the case without reaching an ultimate decision. The practical outcome will be the same as a determination of the absence of jurisdiction.

In the Israeli Wall case of 2004, the ICJ engaged in a similar exercise. One of the issues in the case was whether the ICJ should exercise its discretion and should thus refrain from exercising jurisdiction in this highly political case. After considering various aspects of the case, the ICJ concluded that it has jurisdiction to provide its opinion to the General Assembly, and that there is no compelling reason for it to use its discretionary power not to give that opinion. ${ }^{102}$ It appears, however, that if the ICJ had applied the political question doctrine theory as outlined above, it could have provided a more reasoned and organized decision on that issue.

Using the political question doctrine and expanding it to make it more appropriate to the international context, the ICJ will be able to establish its own rule of justiciability. Through such jurisprudence, the ICJ may decline a judicial review even if it has the jurisdiction to perform one. This two-step analysis for the ICJ to exercise judicial review will be able to standardize the process and thus enhance the legitimacy of the review. The process is summarized in the diagram below.

areas of judicial expertise?, and (iii) Do prudential considerations counsel against judicial intervention?

101 Of course, this argument can have the reverse effect: some could argue that the mere taking of the case in a highly politically charged incident constitutes the lack of respect.

102 See Israeli Wall Case, loc. cit., n. 61, at paras. 43-65. 


\section{CONCLUSION: INTERNATIONAL "RULE OF LAW"}

Pascal has stated that strength without justice is tyrannical, and justice without strength is a mockery; therefore, it is important that the Security Council as an organ with strength and the ICJ as an organ with justice cooperate with and respect each other. More importantly, it is crucial to understand that the current Charter does permit the ICJ to exercise its judicial review authority over the actions of the Security Council. The Pan Am 103 case provided the ICJ with an important opportunity to re-focus its attention on the important question of the extent to which the Security Council functions within the constraints of international law. ${ }^{103}$ The dominance of the US and its allies in the Security Council has caused serious doubts among nations regarding the neutrality of the Security Council's decision-making process. If rogue states present a problem, so too does a rogue Security Council. The rationale that the Security Council can do whatever it deems appropriate appears equivalent to saying that the Security Council can do no wrong, a statement never to be accepted in the millennia of the rule of law. ${ }^{104}$

A judicial review by the ICJ does not have to be a "direct" review as seen in a domestic legal setting. In fact, the spirit of the current Charter prohibits such a direct judicial review, given the judicial supremacy of the ICJ and the co-operation, co-existence and co-involvement of the ICJ and the Security Council in important world affairs. ${ }^{105}$ The Security Council and the ICJ exercise their competence and authority independently and separately. ${ }^{106}$ The Security Council should not ignore the ICJ and the ICJ should not hamper the operation of the Security Council in dealing with emergency issues around the world.

In exercising judicial review over Security Council actions, the ICJ may consider a two-step analysis. The first is whether the ICJ indeed has jurisdiction in that case, whether as an advisory opinion or as a contentious case. The existence of legitimate jurisdiction over a particular case provides the presumption that the ICJ is also authorized judicially to review all relevant legal issues, even including those related actions of the Security Council. The Security Council should not lodge a complaint just because its actions are reviewed by the ICJ. Such "supremacy of the Security Council" is equally erroneous as is the "supremacy of the ICJ," and the case precedents of the ICJ clearly reject such a "supremacy" or "exclusivity" theory. Instead,

\footnotetext{
103 Gardam, loc. cit., n. 16, at 290.

104 See generally Brownlie, Ian, "The decisions of political organs of the United Nations and the rule of law", in Macdonald, Ronald St. John (ed.), Essays in honor of Wang Tieya (London: Martinus Nijhoff Publishers, 1994, 1994); see Sabahi, loc. cit., n. 57, at 9; Arias, Inocencio, "Humanitarian intervention: Could the Security Council kill the United Nations?”, 23 Fordham Int'l L. J. (2000), at 1013-14; Fishman, Andrew K., "Between Iraq and a hard place: the use of economic sanctions and threats to international peace and security", 13 Emory Int'l L. Rev. (1999), at 727.

105 See Ren and Cronin-Furman, loc. cit., n. 86, at 460-62.

106 See Fassbender, loc. cit., n. 4, at 4.
} 
they stand for cooperation, co-existence and co-involvement on the parts of the Security Council and the ICJ.

The second step relates to a more substantive analysis by the ICJ. Even if the ICJ duly finds it has jurisdiction in a particular case, if it determines that reviewing the case and reaching a decision would undermine the basic principles of the United Nations or the integrity of the Security Council, it should refuse to review the case. The actions of the Security Council will remain legitimate and stand as such. The ICJ may consider applying the so-called political question doctrine developed in domestic jurisprudence as a starting point from which to develop its own standard.

A more activist World Court could, if able to maintain a cautious stance not to overstep its Charter boundaries, transform itself from a UN backwater into an institution of major political importance. ${ }^{107}$ The current efforts at the United Nations to reform the Security Council may provide an important catalyst towards addressing this issue more directly; it could include an explicit provision in this respect. The focus of the current efforts should be how, in the operation of the Security Council, to enhance the "rule of law" beyond discussions on the number of permanent members of the Security Council. As a final note, let me repeat the conclusion of Bernd Martenczuk:

There is no contradiction between the rule of law and international peace and security. By promoting the former, the International Court of Justice will contribute to the maintenance of the latter. ${ }^{108}$

\footnotetext{
107 See Watson, loc. cit., n. 4, at 33. This will be particularly the case because as time goes by the ICJ will encounter increasing numbers of cases where relevant states call on the ICJ to review the legitimacy of the Security Council's action. See Sabahi, loc. cit. n. 57, at 47.

108 Martenczuk, loc. cit., n. 1, at 520-22.
} 

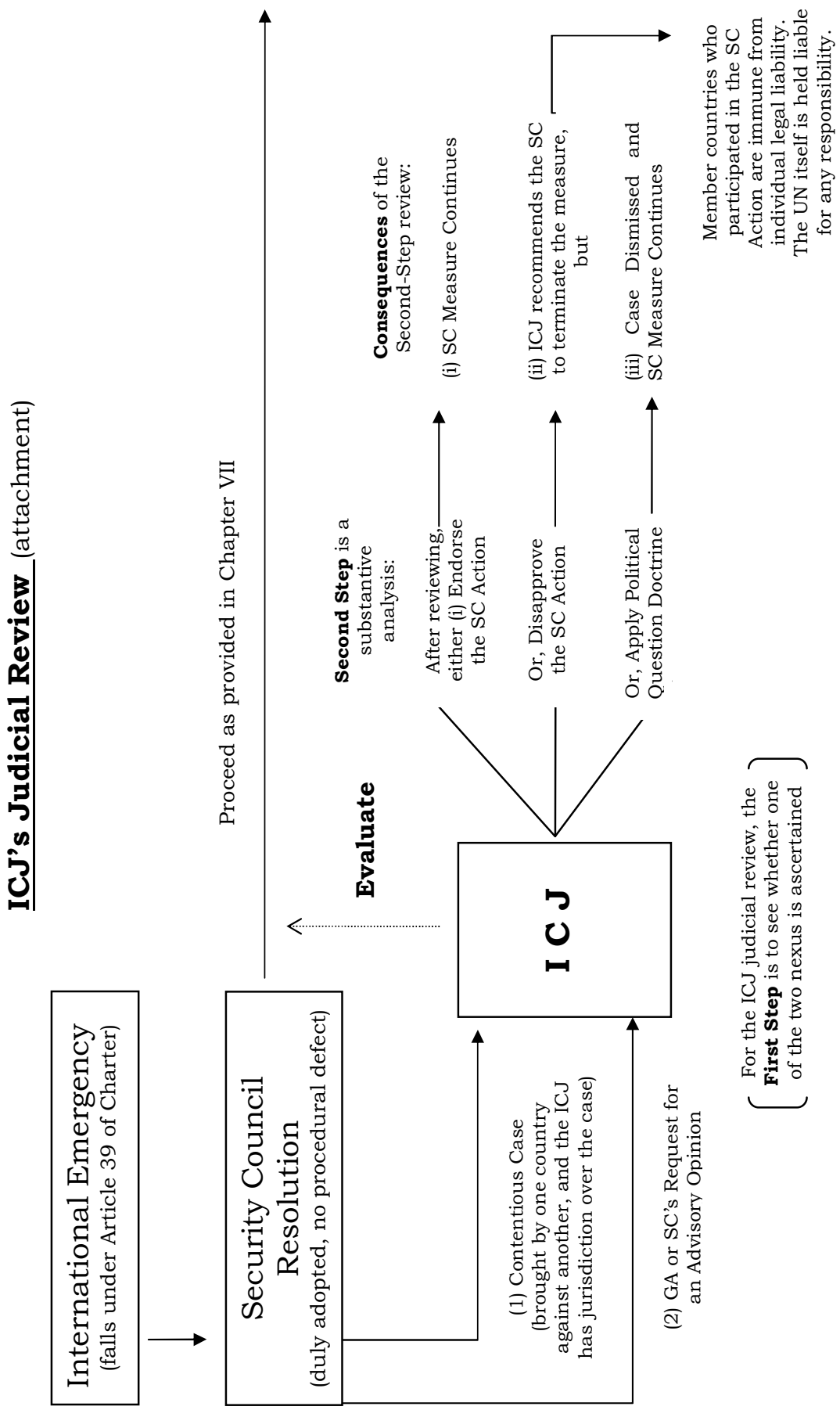